\title{
PENGARUH LINGKUNGAN KERJA, KOMPETENSI DAN IKLIM ORGANISASI TERHADAP KINERJA PEGAWAI PADA BANK BJB CABANG TASIKMALAYA
}

\author{
Dinie Anisa Triastuti \\ Alumni Program Studi Magister Manajemen, Program Pascasarjana, Universitas Galuh \\ dinianisa@gmail.com
}

\author{
Article History : \\ Recieved 12 Desember 2017 \\ Recieved in revished form \\ 26 Desember 2017 \\ Acepted 30 Desember 2017 \\ Available offline 28 Januari 2018 \\ Available online 29 Januari 2018
}

\section{Language Transcript :}

Indonesia

Key Words :

Lingkungan Kerja,

Kompetensi,

Iklim Organisasi,

Kinerja Pegawai,

\begin{abstract}
Tujuan penelitian ini adalah untuk mempelajari, mengetahui, dan menganalisis lingkungan kerja, kompetensi dan iklim organisasi terhadap kinerja pegawai Pada Bank BJB Cabang Tasikmalaya. Sedangkan metode yang digunakan dalam penelitian ini adalah survey explanatory dengan pendekatan kuantitatif, sedangkan teknis analisis data, yaitu statistik deskriptif Analisis dan Statistik Induktif (Inferensial) dengan menggunakan dengan Regresi Berganda (Multiple Regression). Hasil penelitian dan pembahasan memperlihatkan bahwa lingkungan kerja berpengaruh positif terhadap kinerja pegawai. Artinya jika lingkunga kerja ditingkatkan, maka kinerja pegawaiakan meningkat pula.Kompetensi berpengaruh positif terhadap kinerja pegawai. Sehingga jika kompetensi ditingkatkan, maka kinerja pegawaiakan meningkat pula. Iklim organisasi berpengaruh positif terhadap kinerja pegawai. hasilnya jika iklim organisasi ditingkatkan, maka kinerja pegawaiakan meningkat pula. Lingkungan kerja, kompetensi dan iklim organisasi berpengaruh positif terhadap kinerja pegawai. Dalam implementasinya jika lingkungan kerja, kompetensi dan iklim organisasi ditingkatkan, maka kinerja pegawaiakan meningkat pula. Dengan demikian seluruh hipotesis dapat teruji kebenarannya atau signifikan karena $F$ hitung $>F_{\text {tabel }}$ dengan $p$-Value 0,000 atau dibawah 0,05.
\end{abstract}

\section{PENDAHULUAN}

Suatu instansi didirikan karena mempunyai tujuan yang ingin dicapai. Dalam mencapai tujuannya setiap instansi dipengaruhi oleh perilaku dan sikap orang-orang yang terdapat dalam instansi tersebut. Keberhasilan untuk mencapai tujuan tersebut tergantung kepada keandalan dan kemampuan pegawai dalam mengoperasikan unit-unit kerja yang terdapat di instansi tersebut.

Organisasi merupakan suatu sistem yang saling mempengaruhi satu sama lain, apabila salah satu dari sub sistem tersebut rusak, maka akan mempengaruhi sub-sub sistem yang lain. Sistem tersebut dapat berjalan dengan semestinya jika individuindividu yang ada di dalamnya berkewajiban mengaturnya, yang berarti selama anggota atau individunya masih suka dan melaksanakan tanggung jawab sebagaimana mestinya maka organisasi tersebut akan berjalan dengan baik.

Sumber Daya Manusia (SDM) merupakan unsur yang strategis dalam menentukan sehat tidaknya suatu organisasi. Pengembangan SDM yang terencana dan berkelanjutan merupakan kebutuhan yang 
mutlak terutama untuk masa depan organisasi. Dalam kondisi lingkungan tersebut, manajemen dituntut untuk mengembangkan cara baru untuk mempertahankan pegawai pada produktifitas tinggi serta mengembangkan potensinya agar memberikan kontribusi maksimal pada organisasi.

Masalah sumber daya manusia yang kelihatannya hanya merupakan masalah intern dari suatu organisasi sesungguhnya mempunyai hubungan yang erat dengan masyarakat luas sebagai pelayanan publik yang diukur dari kinerja. "Kinerja pegawai adalah hasil kerja secara kualitas dan kuantitas yang dicapai oleh seorang pegawai dalam melaksanakan tugasnya sesuai dengan tanggungjawab yang diberikan kepadanya"(Mangkunegara, 2009:9).

Kinerja pegawai adalah salah satu faktor utama yang mempengaruhi kemajuan organisasi. Semakin tinggi atau semakin baik kinerja pegawai maka tujuan organisasi akan semakin mudah dicapai, begitu pula sebaliknya yang terjadi apabila kinerja pegawai rendah. Kinerja merupakan suatu hal yang tidak dapat dipisahkan dengan organisasi. Kinerja dipengaruhi oleh beberapa faktor diantaranya adalah lingkungan kerja, kompetensi dan iklim organisasi. Lingkungan kerja memiliki arti penting dalam mempengaruhi kinerja. Analisa (2011:20) menyatakan bahwa "lingkungan kerja adalah sesuatu yang ada di sekitar pegawai dan dapat mempengaruhi dirinya dalam menjalankan tugas yang dibebankan".

Kondisi dan suasana lingkungan kerja yang baik akan dapat tercipta dengan adanya penyusunan organisasi secara baik dan benar sebagaimana yang dikatakan oleh Sarwoto (1991) seperti dikutip Analisa (2011:21) menyatakan bahwa suasana kerja yang baik dihasilkan terutama dalam organisasi yang tersusun secara baik, sedangkan suasana kerja yang kurang baik banyak ditimbulkan oleh organisasi yang tidak tersusun dengan baik pula.

Pegawai juga harus memiliki kompetensi yang tepat di dalam melakukan pekerjaannya untuk mewujudkan kinerja dan keberhasilan kerja pegawai dalam jangka panjang. Peningkatan kinerja pegawai secara perorangan akan mendorong kinerja sumber daya manusia secara keseluruhan, yang direkfleksikan dalam kenaikan produktivitas. Pada manajemen kinerja kompetensi lebih berperan pada dimensi perilaku individu dalam menyesuaikan suatu pekerjaan dengan baik. Menurut Alain D. Mitrani, Spencer and Spencer yang dialih bahasakan oleh Surya Dharma ( 2005: 109 ) mengemukakan kompetensi yaitu :(An underlying characteristic's of an individual which is causally related to criterion referenced effective and or superior performance in a job or situantion). Artinya kurang lebih sebagai karakteristik yang mendasari seseorang dan berkaitan dengan efektivitas kerja individu dalam pekerjaannya.

Iklim organisasi Menurut Wirawan (2008:122) adalah persepsi anggota organisasi (secara individual atau kelompok) dan mereka yang secara tetap berhubungan dengan organisasi mengenai apa yang ada atau terjadi dilingkungan internal organisasi secara rutin, yang mempengaruhi sikap dan perilaku organisasi dan kinerja anggota organisasi yang kemudian menentukan kinerja organisasi. Bank BJB Cabang Tasikmalaya merupakan bank pemerintah yang memiliki kontribusi cukup penting dalam perekonomian daerah, tentunya memerlukan pegawai yang bisa mewujudkan tujuan organisasi dan menjalankan tugas dan pekerjaannya. Selain itu pegawai Bank BJB dituntut untuk mampu menangani masalah dan 
kendala-kendala dalam mencapai target organisasi yang telah ditentukan.

Kondisi yang ada di Bank BJB Cabang Tasikmalaya menunjukkan bahwa sebagian pegawai kepuasan yang diperoleh belum optimal serta kinerja yang belum optimal, hal ini ditunjukkan dari kurangnya perhatian dan dukungan dari pimpinan, masih kurangnya kerjasama antar divisi, kompetensi pegawai masih jauh dari yang diharapkan organisasi, cepatnya perkembangan teknologi informasi tidak diikuti dengan peningkatan pengetahuan, keterampilan dan sikap kerja pegawai sehingga hasil kerja yang dihasilkan belum optimal, banyaknya pegawai yang kurang disiplin menjalankan peraturan dan prosedur kerja yang ditetapkan organisasi, Penghargaan yang belum sesuai dengan pekerjaan yang telah dilakukan, belum optimalnya dukungan antara anggota kelompok kerjapenyelesaian pekerjaan melewati target waktu yang ditetapkan dan masih mendapatkan komplain dari atasan. Penelitian ini ditujukan untuk mempelajari, mengetahui, dan menganalisis pengaruh lingkungan kerja, kompetensi dan iklim organisasi terhadap kinerja pegawai Pada Bank BJB Cabang Tasikmalaya.

\section{METODOLOGI}

Dalam penelitian ini digunakan Metode yang digunakan dalam penelitian ini adalah survey explanatory. Menurut Kerlinger yang dikutip oleh Sugiyono (2010:17) "metode survey yaitu metodologi penelitian yang digunakan pada populasi besar maupun kecil, tetapi data yang dipelajari adalah data dari sampel yang diambil dari populasi tersebut, sehingga ditemukan kejadian-kejadian relatif, distribusi dan hubungan-hubungan antar variabel sosiologis maupun psikologis.

Desain/jenis penelitian yang akan digunakan dalam penyusunan tesis ini adalah desain penelitian kuantitatifyaitu desain yang dilakukan pada empirik tidak secara mendalam melainkan meluas, untuk memperoleh pengetahuan ilmiah yang bersifat abstarak, general dan universal (Rusidi dan Enas, 2011:27).

Tempat /lokasi penelitian dilakukan di Bank BJB Cabang Tasikmalaya.Objek penelitian terdiri dari dua elemen, yaitu populasi dan sampel. Populasi dalam penelitian ini adalah Populasi dalam penelitian ini adalah seluruh pegawai Bank BJB Cabang Tasikmalaya sebanyak 40 orang.Proses pengambilan sampel dalam penelitian ini adalah dengan menggunakan teknik total sampling. jadi seluruh pegawai Bank BJB Cabang Tasikmalaya sebanyak 40 orang dijadikan sampel utama.

Data yang digunakan dalam penelitian ini adalah data primer dan data sekunder. Sumber data primer diperoleh dari hasil penyebaran angket kepada Seluruh pegawaiBank BJB Cabang Tasikmalaya. Sedangkan data sekunder diperoleh dari Bank BJB Cabang Tasikmalaya.

Teknik dan instrumen pengumpulan data diusahakan untuk mendapatkan data yang dibutuhkan dalam analisis tesis ini. Pengumpulan data tersebut meliputi:

1) Observasi, yaitu mengamati kegiatan di Bank BJB Cabang Tasikmalaya.

2) Kuesioner, yang diberikan kepada seluruh pegawai Bank BJB Cabang Tasikmalaya, dengan cara mengajukan pertanyaan yang secara logis berhubungan dengan masalah penelitian dan bersifat pertanyaan tertutup/berstruktur yang menyangkut pendapat responden tentang pengaruh lingkungan kerja, kompetensi dan iklim organisasi terhadapkinerja pegawai.

Teknik Analisis data yang digunakan dalam penelitian ini adalah:

1) Uji validitas, Uji validitas ini dimaksudkan untuk menguji seberapa baik instrument penelitian mengukur konsep yang seharusnya diukur. Untuk mengetahui apakah item-item 
pertanyaan yang tersaji dalam kuesionar benar-benar mempu mengungkapkan dengan pasti tentang apa yang akan diteliti.

2) Uji Reliabilitas, Koefisien reliabilitas istrumen dimaksudkan untuk melihat konsistensi jawaban butir-butir pernyataan yang diberikan oleh responden.

3) Statistik deskriptif, Teknik analisis statistik deskriptif yang digunakan dalam penelitian ini adalah untuk mengetahui karakteristik responden dan untuk mengetahui kriteria deskripsi dari masing-masing variabel yang diteliti.

4) Analisis Statistik Induktif (Inferensial), yaitu analisis yang digunakan untuk menguji pengaruh variabel independen terhadap variabel dependen. Alat analisis yang digunakan dalam penelitian ini adalah Regresi Berganda (Multiple Regression), untuk mengetahui pengaruh keseluruhan variabel bebas terhadap variable terikat, dan uji signifikansi koefisien determinasi secara keseluruhan di uji dengan uji $\mathrm{F}$, sedangkan untuk menguji signifikansi koefisien determinasi masing-masing variabel bebas secara parsial digunakan uji t.

\section{HASIL DAN PEMBAHASAN}

\subsection{Pengaruh Lingkungan Kerja Terhadap Kinerja Pegawai}

Interprestasi hasil pengujian hipotesis melalui analisis regresi untuk pengaruh lingkungan kerja terhadap kinerja pegawai dengan menggunakan program SPSS sebagaimana pada Tabel 1 .

Berdasarkan tabel coefficientsdiketahui bahwa hubungan antara variabel lingkungan kerja dengan kinerja pegawai yang dihitung dengan koefisien korelasi yaitu diambil dari akar kuadrat dari nilai beta $\sqrt{ }(0,361)$ adalah 0,600 . Berdasarkan Tabel 2 angka tersebut menunjukkan bahwa terdapat hubungan yang sedang antara variabel (X1) dengan (Y). Untuk menyatakan besar kecilnya kontribusi (sumbangan) variabel (X1) terhadap (Y), dapat dilihat bahwa koefisien determinan sebesar $(0,361)^{2}=0,130$. Artinya kinerja pegawai dipengaruhi oleh lingkungan kerja sebesar $13,0 \%$, sedangkan sisanya sebesar $87,0 \%$ dipengaruhi faktor lain yang tidak diteliti. Dengan demikian dapat disimpulkan bahwa terdapat pengaruh positif antara variabel lingkungan kerja terhadap kinerja pegawai.

Berdasarkan tabel coefficientstersebut pun dapat dilihat bahwa nilai $\mathrm{t}$ hitung adalah sebesar 2,920 dengan signifikasi $0,006<0,05$. Dan nilai $t_{\text {tabel }}$ dengan $\mathrm{df}=40$ $2=38$ pada tingkat signifikasi $5 \%$ adalah sebesar 2,024. Dengan demikian, karena $t_{\text {hitung }} 2,920>t_{\text {tabel }} 2,024$, dapat disimpulkan bahwa Ho ditolak. Artinya, terdapat pengaruh positif antara variabel lingkungan kerja (X1) terhadap kinerja pegawai(Y).

Berdasarkan hasil analisis diperoleh kenyataan bahwa terdapat hubungan yang sedang antara variabel lingkungan kerja dengan kinerja pegawai. Hasil penelitian ini sejalan dengan pendapat Hasil penelitian ini sejalan dengan pendapat Nitisemito dalam Analisa (2011:24) menyatakan bahwa suatu kondisi lingkungan kerja dapat dikatakan baik sesuai apabila pegawai dapat melaksanakan kegiatan secara optimal, sehat, aman, dan nyaman, sedangkan lingkungan kerja yang kurang baik menuntut tenaga kerja dan waktu yang lebih banyak dan tidak mendukung diperolehnya rancangan sistem kerja yang efisien. Lingkungan kerja yang kondusif dapat berpengaruh langsung terhadap pegawai dalam meningkatkan kinerja pegawai. Sebaliknya lingkungan kerja yang tidak memadai akan dapat menurunkan 
kinerja pegawai. Suatu lingkungan kerja dikatakan baik apabila manusia dapat melaksanakan kegiatan secara optimal, sehat, aman, nyaman. Berdasarkan hal tersebut dapat dikatakan jika lingkungan kerja ditingkatkan maka kinerja pegawai dapat meningkat pula.

\subsection{Pengaruh Kompetensi terhadap Kinerja Pegawai}

Interprestasi hasil pengujian hipotesis melalui analisis regresi untuk pengaruh kompetensi terhadap kinerja pegawai dengan menggunakan program SPSS, sebagaimana pada Tabel 2.

Berdasarkan Tabel 2 diketahui bahwa hubungan antara variabel kompetensi dengan kinerja pegawai yang dihitung dengan koefisien korelasi yaitu diambil dari akar kuadrat dari nilai beta $\sqrt{ }(0,314)$ adalah 0,560. Berdasarkan Tabel 2, angka tersebut menunjukkan besar kecilnya kontribusi (sumbangan) variabel (X2) terhadap (Y), dapat dilihat bahwa koefisien determinan sebesar $(0,314)^{2}=0,098$. Artinya kinerja pegawaidipengaruhi oleh kompetensi sebesar $9,8 \%$, sedangkan sisanya sebesar $90,2 \%$ dipengaruhi faktor lain yang tidak diteliti. Dengan demikian dapat disimpulkan bahwa terdapat pengaruh positif antara variabel kompetensi terhadap kinerja pegawai.

Berdasarkan Tabel 2 tersebut pun dapat dilihat bahwa nilai $\mathrm{t}$ hitung adalah sebesar 2,595 dengan signifikasi $0,014<0,05$. Dan nilai $\mathrm{t}$ tabel dengan $\mathrm{df}=40-2=38$ pada tingkat signifikasi 5\% adalah sebesar 2,024. Dengan demikian, karena $t_{\text {hitung }} 2,595>t_{\text {tabel }}$ 2,024, dapat disimpulkan bahwa Ho ditolak. Artinya, terdapat pengaruh positif antara variabel kompetensi terhadap kinerja pegawai.

Berdasarkan hasil analisis diperoleh kenyataan bahwa terdapat hubungan yang sedangantara variabel kompetensi dengan kinerja pegawai. Hasil penelitian ini sejalan dengan pendapat Menurut Alain D. Mitrani, Spencer and Spencer yang dialih bahasakan oleh Surya Dharma (2005: 109 ) mengemukakan kompetensi yaitu :(An underlying characteristic's of an individual which is causally related to criterion referenced effective and or superior performance in a job or situantion). Artinya kurang lebih sebagai karakteristik yang mendasari seseorang dan berkaitan dengan efektivitas kerja individu dalam pekerjaannya.

Betapa pentingnya kinerja bagi organisasi sehingga pengembangan pegawai berbasis kompetensi merupakan salah satu upaya dapat meningkatkan kinerja, karena pengembangan pegawai berbasis kompetensi merupakan wujud perhatian dan pengakuan perusahaan atau pimpinan kepada pegawai yang menunjukan kemampuan kerja, kerajinan, dan kepatuhan serta disiplin kerja. Berdasarkan hal tesebut jika kompetensi ditingatkan maka kinerja pegawai meningkat pula.

\subsection{Pengaruh Iklim Organisasi terhadap Kinerja Pegawai}

Interprestasi hasil pengujian hipotesis melalui analisis regresi untuk pengaruh iklim organisasi terhadap kinerja pegawai dengan menggunakan program SPSS, penulis sajikan dalam Tabel 3sebagai berikut.

Berdasarkan Tabel 3 diketahui bahwa hubungan antara variabel iklim organisasi dengan kinerja pegawai yang dihitung dengan koefisien korelasi yaitu diambil dari akar kuadrat dari nilai beta $\sqrt{ }(0,313)$ adalah 0,559. Berdasarkan tabel 3.3. angka tersebut menunjukkan bahwa terdapat hubungan yang sedang antara variabel (X3) dengan (Y). Untuk menyatakan besar kecilnya kontribusi (sumbangan) variabel (X3) terhadap (Y), dapat dilihat bahwa koefisien determinan sebesar $(0,313)^{2}=$ 0,098 . Artinya kinerja pegawai dipengaruhi oleh iklim kerja sebesar 9,8\%, sedangkan 
sisanya sebesar $90,2 \%$ dipengaruhi faktor lain yang tidak diteliti. Dengan demikian dapat disimpulkan bahwa terdapat pengaruh positif antara variabel iklim organisasi terhadap kinerja pegawai.

Berdasarkan Tabel 3 tersebut pun dapat dilihat bahwa nilai $\mathrm{t}$ hitung adalah sebesar 2,565 dengan signifikasi $0,015<0,05$. Dan nilai $\mathrm{t}$ tabel dengan $\mathrm{df}=40-2=38$ pada tingkat signifikasi 5\% adalah sebesar 2,024. Dengan demikian, karena $t_{\text {hitung }} 2,565>t_{\text {tabel }}$ 2,024, dapat disimpulkan bahwa Ho ditolak. Artinya, terdapat pengaruh positif antara variabel iklim organisasi terhadap kinerja pegawai.

Berdasarkan hasil analisis diperoleh kenyataan bahwa terdapat hubungan yang sedang antara variabel iklim organisasi dengan kinerja pegawai. Hasil penelitian ini sejalan denganWirawan (2008:122) iklim organisasi adalah persepsi anggota organisasi (secara individual atau kelompok) dan mereka yang secara tetap berhubungan dengan organisasi mengenai apa yang ada atau terjadi dilingkungan internal organisasi secara rutin, yang mempengaruhi sikap dan perilaku organisasi dan kinerja anggota organisasi yang kemudian menentukan kinerja organisasi. Menurut Stringer dalam Wirawan (2007:131-133) dimensi iklim organisasi sebagai berikut : struktur (Structure), standar-standar (Standards), Tanggung Jawab (Responsibility), Penghargaan (Recognition, dan Dukungan (Support).

Iklim organisasi yang kondusif memberikan rasa aman dan memungkinkan para pegawai untuk dapat berkerja optimal. Dibutuhkan iklim organisasi yang kondusif untuk menunjang pelaksanaan tugas karyawan. Iklim organisasi merupakan faktor yang penting dalam usaha peningkatan kinerja karyawan di perusahaan. Semakin tinggi iklim organisasi semakin tinggi pula kinerja pegawai.

\subsection{Pengaruh Lingkungan Kerja, Kompetensi dan Iklim Organisasi terhadap Kinerja Pegawai}

Interprestasi hasil pengujian hipotesis melalui analisis regresi untuk pengaruh lingkungan kerja, kompetensi dan iklim organisasi terhadap kinerja pegawai dengan menggunakan program SPSS, sebagaimana disajikan dalam Tabel 4.

Berdasarkan Tabel 4 diketahui bahwa hubungan antara variabel lingkungan kerja, kompetensi dan iklim organisasi dengan kinerja pegawai yang dihitung dengan koefisien korelasi adalah 0,928. Berdasarkan tabel 3.3. angka tersebut menunjukkan bahwa terdapat hubungan yang sangat tinggi antar variabel. Untuk menyatakan besar kecilnya kontribusi (sumbangan) antar variabel dapat dilihat bahwa koefisien determinan sebesar 0,849. Artinya kinerja pegawai dipengaruhi oleh lingkungan kerja, kompetensi dan iklim kerja sebesar $84,9 \%$, sedangkan sisanya sebesar $15,1 \%$ dipengaruhi faktor lain yang tidak diteliti. Dengan demikian dapat disimpulkan bahwa terdapat pengaruh positif antara variabel lingkungan kerja, kompetensi dan iklim organisasi terhadap kinerja pegawai. Sedangkan dengan menggunakan uji anova, maka penulis sajikan dalam Tabel 5 sebagai berikut.

Berdasarkan Tabel 5 dapat dilihat bahwa diperoleh $F_{\text {hitung }}$ sebesar 73,900 dengantingkat signifikasi $0,000<0,05$. Dan nilai $\mathrm{F}_{\text {tabel }}$ dengan $\mathrm{dk}=40-2=38$ maka diperoleh $F_{\text {tabel }} 2,85$. Dengan demikian karena $F_{\text {hitung }} 73,900>F_{\text {tabel }} 2,85$, dapat disimpulkan bahwa ho ditolak. Artinya terdapat pengaruh positif antara lingkungan kerja, kompetensi dan iklim organisasi terhadap kinerja pegawai. 
Tabel 1. Koefisien Korelasi Lingkungan Kerja Terhadap Kinerja Pegawai

\begin{tabular}{|c|c|c|c|c|c|c|}
\hline \multirow[b]{2}{*}{ Mod } & & \multicolumn{2}{|c|}{$\begin{array}{c}\text { Unstandardized } \\
\text { Coefficients }\end{array}$} & \multirow{2}{*}{$\begin{array}{c}\text { Standardized } \\
\text { Coefficients } \\
\text { Beta }\end{array}$} & \multirow[b]{2}{*}{$\mathrm{t}$} & \multirow[b]{2}{*}{ Sig. } \\
\hline & & $B$ & Std. Error & & & \\
\hline 1 & (Constant) & .235 & .274 & & .859 & .396 \\
\hline & Lingkungan_Kerja & .340 & .117 & .361 & 2.920 & .006 \\
\hline & Kompetensi & .318 & .123 & .314 & 2.595 & .014 \\
\hline & Iklim_Kerja & .286 & .112 & .313 & 2.565 & .015 \\
\hline
\end{tabular}

a. Dependent Variable: Kinerja_Pegawai

Tabel 2. Koefisien Korelasi Kompetensi Terhadap Kinerja Pegawai

\begin{tabular}{|c|c|c|c|c|c|c|}
\hline \multirow{2}{*}{\multicolumn{2}{|c|}{ Model }} & \multicolumn{2}{|c|}{$\begin{array}{l}\text { Unstandardized } \\
\text { Coeff icients }\end{array}$} & \multirow{2}{*}{$\begin{array}{c}\text { Standardized } \\
\text { Coefficients } \\
\text { Beta }\end{array}$} & \multirow[b]{2}{*}{$\mathrm{t}$} & \multirow[b]{2}{*}{ Sig. } \\
\hline & & $\mathrm{B}$ & Std. Error & & & \\
\hline \multirow[t]{4}{*}{1} & (Constant) & .235 & .274 & & .859 & .396 \\
\hline & Lingkungan_Kerja & .340 & .117 & .361 & 2.920 & .006 \\
\hline & Kompetensi & .318 & .123 & .314 & 2.595 & .014 \\
\hline & Iklim_Kerja & .286 & .112 & .313 & 2.565 & .015 \\
\hline
\end{tabular}

a. Dependent Variable: Kinerja_Pegawai

Tabel 3. Koefisien Korelasi Iklim Organisasi terhadap Kinerja Pegawai

\begin{tabular}{|c|c|c|c|c|c|c|}
\hline \multirow{2}{*}{\multicolumn{2}{|c|}{ Model }} & \multicolumn{2}{|c|}{$\begin{array}{l}\text { Unstandardized } \\
\text { Coeff icients }\end{array}$} & \multirow{2}{*}{$\begin{array}{l}\text { Standardized } \\
\text { Coeff icients } \\
\text { Beta }\end{array}$} & \multirow[b]{2}{*}{$t$} & \multirow[b]{2}{*}{ Sig. } \\
\hline & & $\mathrm{B}$ & Std. Error & & & \\
\hline \multirow[t]{4}{*}{1} & (Constant) & .235 & .274 & & .859 & .396 \\
\hline & Lingkungan_Kerja & .340 & .117 & .361 & 2.920 & .006 \\
\hline & Kompetensi & .318 & .123 & .314 & 2.595 & .014 \\
\hline & Iklim_Kerja & .286 & .112 & .313 & 2.565 & .015 \\
\hline
\end{tabular}

a. Dependent Variable: Kinerja_Pegawai

Tabel 4. Pengaruh Lingkungan Kerja, Kompetensi

dan Iklim Organisasi terhadap Kinerja Pegawai

\begin{tabular}{|l|r|r|r|r|}
\hline Model & $\mathrm{R}$ & $\mathrm{R}$ Square & $\begin{array}{c}\text { Adjusted } \\
\text { R Square }\end{array}$ & $\begin{array}{r}\text { Std. Error of } \\
\text { the Estimate }\end{array}$ \\
\hline 1 & $.928^{\mathrm{a}}$ & .860 & .849 & .32007 \\
\hline
\end{tabular}

a. Predictors: (Constant), Iklim_Kerja, Kompetensi, Lingkungan_Kerja 
Berdasarkan Tabel 3. coefficients kita bisa menyusun matriks jalur yaitu sebagai berikut:

$\begin{array}{ll}\operatorname{\rho yx}_{1} & =0,361 \\ \operatorname{pyx}_{2} & =0,314 \\ \operatorname{\rho yx}_{3} & =0,313\end{array}$

Dari Beta tersebut dapat dihitung koefisien jalur variabel lain diluar model yakni Pyś dengan rumus: Pyź $=1-0,860=0,140$.

Berdasarkan hasil analisis diperoleh kenyataan bahwa terdapat hubungan yang sangat tinggi antara variabel lingkungan kerja, kompetensi dan iklim organisasi terhadap kinerjapegawai. Penelitian ini sejalan dengan pendapat Simamora (2012:19) yang mengemukakan bahwa kinerja pegawai adalah tingkatan dimana para pegawai mencapai persyaratanpersyaratan pekerjaan. Kinerja mengacu pada kadar pencapaian tugas-tugas yang membentuk sebuah pekerjaan karyawan.

Lingkungan kerja memiliki arti penting dalam mempengaruhi kepuasan kerja dan kinerja pegawai. Analisa (2011:20) menyatakan bahwa "lingkungan kerja adalah sesuatu yang ada di sekitar pegawai dan dapat mempengaruhi dirinya dalam menjalankan tugas yang dibebankan". Sedarmayanti (2001) seperti dikutip Analisa (2011:21) menyatakan bahwa secara garis besar, jenis lingkungan kerja terbagi menjadi 2 yaitu hubungan kerja dan lingkungan kerja non- fisik yang terdiri dari struktur kerja, tanggung jawab kerja, perhatian dan dukungan pemimpin,kerja sama antar kelompok, kelancaran komunikasi.

Kompetensi diperlukan untuk mewujudkan kepuasan kerja dan keberhasilan kerja pegawai dalam jangka panjang. Menurut Alain D. Mitrani, Spencer and Spencer yang dialih bahasakan oleh Surya Dharma ( 2005: 109 ) mengemukakan kompetensi yaitu :(An underlying characteristic's of an individual which is causally related to criterion referenced effective and or superior performance in a job or situantion). Artinya kurang lebih sebagai karakteristik yang mendasari seseorang dan berkaitan dengan efektivitas kerja individu dalam pekerjaannya.

Spencer dan Spencer (dalam Palan, 2007:6), menguraikan lima karakteristik yang membentuk kompetensi, sebagai berikut: Pengetahuan, keterampilan, konsep diri dan nilai-nilai, karakteristik pribadi, dan motif. Menurut Wirawan (2008:122) iklim organisasi adalah persepsi anggota organisasi (secara individual atau kelompok) dan mereka yang secara tetap berhubungan dengan organisasi mengenai apa yang ada atau terjadi dilingkungan internal organisasi secara rutin, yang mempengaruhi sikap dan perilaku organisasi dan kinerja anggota organisasi yang kemudian menentukan kinerja organisasi. Menurut Stringer dalam Wirawan (2007:131-133) dimensi iklim organisasi sebagai berikut : struktur (Structure), standar-standar (Standards), Tanggung Jawab (Responsibility), Penghargaan (Recognition, dan Dukungan (Support).

Iklim organisasi yang kondusif memberikan rasa aman dan memungkinkan para pegawai untuk dapat berkerja optimal. Dibutuhkan iklim organisasi yang kondusif untuk menunjang pelaksanaan tugas karyawan. Iklim organisasi merupakan faktor yang penting dalam usaha peningkatan kinerja karyawan di perusahaan.

Dari uraian yang dikemukakan itu, menunjukkan bahwa lingkungan kerja, kompetensi dan iklim organisasi dikatakan baik apabila pegawai dapat mendapatkan kinerja yang optimal. Oleh karena itu penentuan dan penciptaan bahwa lingkungan kerja, kompetensi dan iklim organisasi yang baik akan sangat menentukan keberhasilan pencapaian tujuan 
organisasi. Sebaliknya apabila bahwa lingkungan kerja, kompetensi dan iklim organisasi yang tidak baik akan dapat menurunkan motivasi serta semangat kerja dan akhirnya dapat menurunkan kepuasan kerja dan kinerja pegawai.

\section{SIMPULAN}

Berdasarkan pembahasan dari hasil penelitian maka dapat disimpulkan beberapa hal yaitu berdasarkan tanggapan responden mengenai lingkungan kerja dengan nilai tertinggi pada indikator hubungan vertikal. Artinya lingkungan kerja sangat dipengaruhioleh indikator hubungan vertikal. Lingkungan kerja berpengaruh positif terhadap kinerja pegawai. Artinya jika lingkungan kerja ditingkatkan, maka kinerja pegawaiakan meningkat pula. Berdasarkan tanggapan responden mengenai kompetensi dengan nilai tertinggi pada indikatorketerampilan dalam melayani Nasabahdan karakteristik pribadi. Artinya kompetensisangat dipengaruhi olehindikator keterampilan dalam melayani Nasabahdan karakteristik pribadi. Kompetensi berpengaruh positif terhadap kinerja pegawai. Artinya jika kompetensi ditingkatkan, maka kinerja pegawaiakan meningkat pula. Berdasarkan tanggapan responden mengenai iklim organisasi dengan nilai tertinggi pada indikator tanggung jawab (responsibility). Artinya iklim organisasi sangat dipengaruhi olehindikator tanggung jawab (responsibility).Iklim organisasi berpengaruh positif terhadap kinerja pegawai. Artinya jika iklim organisasi ditingkatkan, maka kinerja pegawaiakan meningkat pula. Berdasarkan tanggapan responden mengenai kinerja pegawai dengan nilai tertinggi pada indikator kuantitas. Artinya kinerja pegawai sangat dipengaruhi olehindikator kuantitas.Lingkungan kerja, kompetensi dan iklim organisasi berpengaruh positif terhadap kinerja pegawai. Artinya jika lingkungan kerja, kompetensi dan iklim organisasi ditingkatkan, maka kinerja pegawaiakan meningkat pula.

\section{DAFTAR PUSTAKA}

Bernardin, H. John \& Joyce, E. A Russel. 2003. Human Resource management: an experiential approachs. Singapore : MC. Graw Hill Internasional.

Dharma, Surya. 2005. Manajemen Kinerja; Falsafah Teori dan Penerapannya, Yogyakarta : Pustaka Pelajar.

Hasibuan, Malayu SP. 2007. Manajemen Sumber Daya Manusia (Dasar dan Kunci Keberhasilan. Jakarta : Toko Gunung Agung.

Idrus, Muhammad. 2007. Budaya Kerja dan Iklim Organisasi. Jakarta : Erlangga.

Lucky Wulan Analisa. 2011. Manajemen Sumber Daya Manusia. Bandung : Remaja Rosdakarya.

Mangkunegara, Anwar Prabu. 2009. Manajemen Sumber Daya Manusia. Bandung : Remaja Rosdakarya.

Manulang, M. 2007. Manajemen Sumber Daya Manusia. Jakarta : Ghalia Indonesia.

Martini dan Rostiana. 2003. Komitmen Organisasi Ditinjau dari Iklim Organisasi dan Motivasi Berprestasi. Phronesis. Vol. 5. No.9.

Newstrom, John W. And Davis, Keith, 2007. Organizational Behavior, Human Behavior at WorkSingapore : The McGraw-Hill Book Company.

Palan. R. 2007. Competency Management. Teknik Mengimplementasikan Manajemen SDM berbasis Kompetensi untuk Meningkatkan Daya Saing Organisasi. Penerjemah: Octa Melia Jalal. Jakarta : PPM.

Prawirosentono, Suyadi. 2008. Kebijakan Kinerja Karyawan. Yogyakarta : BPFE.

Robbins, Stephen. P. 2006. Perilaku organisasi. Edisi Bahasa Indonesia. Jakarta : PT Indeks Kelompok Gramedia.

Rusidi dan Enas. 2001. Metode Penelitian (Elaborasi Pedoman Penulisan 
Skripsi, Tesis dan Disertasi. Bandung :

Dewa Ruchi.

Sedarmayanti. 2009. Sumber Daya Manusia dan Produktivitas Kerja. Bandung: Mandar Maju.

Simamora, Henry. 2012. Manajemen Sumber Daya Manusia. Yogyakarta : STIE YKPN.

Soelaiman Sukmalana. 2007. Manajemen Kinerja Langkah-langkah efektif Untuk Membangun, Mengendalikan dan Evaluasi Kerja. Jakarta. Intermedia Personalia Utama.

Sugiyono. 2010.Metode Penelitian Administrasi.Bandung : Alfabeta.

Surakhmad,Winarno.2010.Pengantar Penelitian-penilitian Ilmiah. Bandung : Tarsito.

Wirawan. 2007. Budaya dan Iklim Organisasi. Jakarta: Salemba Empat.

Umar, Husein. 2003. Riset Sumber Daya Manusia dalam Organisasi. Jakarta : Gramedia Pustaka Utama. 